\title{
Penerapan Pembelajaran Think Talk Write Untuk Meningkatkan Hasil Belajar Matematika
}

\author{
${ }^{1}$ Rahmatina Aulia, ${ }^{2}$ Nahor Murani Hutapea, ${ }^{3}$ Syofni \\ 1,2,3 Department of Mathematics Education, FKIP, Riau Unversity, Indonesia \\ Email:1rahmatinaaulia@gmail.com,2nahor_hutapea@yahoo.com,3syofnimath@yahoo.com
}

\begin{abstract}
This study aims to improve the learning process and the student's mathematical result by applying Think-Talk-Write strategy in cooperative learning. The research subject were 34 students of class $V_{I I I} I_{1}$ SMPN 12 Pekanbaru. This study was conducted in the odd semester of the academic year 2019/2020. This research is Classromm Action Research with two cycles and each of cycle has four stages: planning, implementation, observation, and reflection. Data in this research are teacher and student activity sheets and student's mathematical result data. The research instuments consists of learning device (Syllabus, Lesson Plans, and Student Activity Sheets) and instruments for data collecting (teacher and students observation sheet and mathematics learning outcome test). The data analysis technique used is descriptive narrative analysis which is done by describing the data collected on the observation sheet. Based on analysis of teacher and student activity sheets was obtained that implementation of learning process on cycle II better than cycle I. The results of this research showed an increasing the number of students who reach the Minimum Completeness Criteria from the base score to cycle I and cycle II.The number of students who reached Minimum Competeness Criteria on the base score was 8 person, in cycle I was 17 person and in cycle II was 27 person. Results of this research indicates that the implementation of Think-Talk-Write strategy in cooperative learning to improve the learning process and improve the student's mathematics result at class VIII $I_{1}$ SMPN 12 Pekanbaru.
\end{abstract}

Key Words:Think-Talk-Write, Cooperative Learning, Learning Result

\begin{abstract}
Abstrak: Penelitian ini bertujuan memperbaiki proses pembelajaran dan meningkatkan hasil belajar matematika peserta didik melalui penerapan strategi Think-Talk-Write dalam pembelajaran

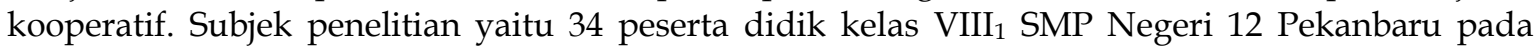
semester ganjil tahun pelajaran 2019/2020. Jenis penelitian yang dilakukan yaitu penelitian tindakan kelas dengan dua siklus dan setiap siklus terdiri dari empat tahapan yaitu: perencanaan, pelaksanaan, pengamatan, dan refleksi. Data dalam penelitian adalah data aktivitas guru dan aktivitas peserta didik serta data tes hasil belajar matematika peserta didik.Instrumen penelitian terdiri dari perangkat pembelajaran (Silabus, Rencana Pelaksanaan Pembelajaran, Lembar Aktivitas Peserta Didik) dan instrumen pengumpul data (lembar pengamatan aktivitas guru dan peserta didik serta tes hasil belajar matematika). Teknik analisis data yang digunakan adalah analisis deksriptif naratif yang dilakukan dengan cara mendeskripsikan data yang terkumpul pada lembar pengamatan. Berdasarkan analisis lembar pengamatan aktivitas guru dan peserta didik diperoleh bahwa pelaksanaan proses pembelajaran pada siklus II lebih baik dari siklus I. Hasil penelitianmenunjukkan terjadi peningkatan jumlah peserta didik yang mencapai Kriteria Ketuntasan Minimum (KKM) dari skor dasar ke siklus I dan Siklus II. Jumlah peserta didik yang mencapai KKM pada skor dasar yaitu 8 orang, pada siklus I 17 orang dan pada siklus II yaitu 27 orang.Hasil penelitian ini menunjukkan bahwa penerapan strategi Think-Talk-Write dalam pembelajaran kooperatif dapat memperbaiki proses pembelajaran dan meningkatkan hasil belajar matematika peserta didik kelas VIII $\mathrm{SMP}_{1}$ Negeri 12 Pekanbaru.
\end{abstract}

Kata Kunci:Think-Talk-Write, Pembelajaran Kooperatif, Hasil Belajar Matematika 


\section{PENDAHULUAN}

Matematika merupakan salah satu mata pelajaran yang diajarkan pada jenjang pendidikan dasar, menengah dan perguruan tinggi.Matematika dinilai cukup memegang peranan penting dalam membentuk peserta didik yang berkualitas karena matematika merupakan sarana berpikir ilmiah, mengembangkan pola pikir logis, rasional, kritis, kreatif, sistematis, dan praktis serta kemampuan bekerjasama (I Made Surat, 2016).Matematika sebagai salah satu mata pelajaran di sekolah bertujuan agar peserta didik memiliki kemampuan: (1) memahami konsep matematika, (2) menggunakan pola sebagai dugaan dalam penyelesaian masalah dan mampu membuat generalisasi berdasarkan fenomena atau data yang ada, (3) menggunakan penalaran pada sifat, melakukan manipulasi matematika dalam penyederhanaan, menganalisa komponen pemecahan masalah, (4) mengkomunikasikan gagasan, penalaran serta mampu menyusun bukti matematika, (5) memiliki sikap menghargai kegunaan matematika dalam kehidupan, (6) memiliki sikap dan prilaku yang sesuai dengan nilai-nilai dalam matematika dan pembelajarannya, (7) melakukan kegiatan-kegiatan motorik yang menggunakan pengetahuan matematika, dan (8) menggunakan alat peraga sederhana maupun hasil teknologi untuk melakukan kegiatan-kegiatan matematika (Permendikbud Nomor 58 Tahun 2014).

Ketercapaian tujuan pembelajaran matematika dapat dilihat dari hasil belajar matematika peserta didik.Hasil belajar yang diharapkan adalah hasil belajar yang mencapai ketuntasan belajar minimal yang telah ditetapkan. Mengenai ketuntasan hasil belajar, Permendikbud Nomor 23 Tahun 2016 tentang Standar Penilaian Pendidikan menyatakan bahwa Kriteria Ketuntasan Minimal (KKM) adalah kriteria ketuntasan belajar yang ditentukan oleh satuan pendidikan. Peserta didik dikatakan tuntas apabila skor hasil belajar peserta didik mencapai KKM yang telah ditetapkan sekolah.Peneliti melakukan wawancara dengan guru matematika untuk mengetahui bagaimana proses pembelajaran yang berlangsung dan untuk mengetahui ketercapaian hasil belajar matematika di kelas VIII 1 SMP Negeri 12 Pekanbaru. Dari hasil wawancara dengan guru diperoleh bahwa masih banyak peserta didik yang belum mencapai KKM yang ditetapkan sekolah yaitu 73 . Hasil ulangan matematika peserta didik kelas VIII ${ }_{1}$ SMP Negeri 12 Pekanbaru pada materi Koordinat Kartesius, presentase peserta didik yang memperoleh skor $\geq 73$ adalah 23,53\% atau 8 dari 34 peserta didik. Guru matematika kelas VIII 1 SMP Negeri 12 Pekanbaru juga mengatakan bahwa ketika proses pembelajaran hanya peserta didik yang berkemampuan tinggi yang aktif ketika diberi pertanyaan dan peserta didik yang berkemampuan sedang dan rendah kurang aktif bertanya apa yang tidak dipahami.

Peneliti selanjutnya melakukan observasi untuk mengetahui bagaimana proses pembelajaran yang berlangsung pada pelajaran matematika di kelas VIII 1 SMP Negeri 12 Pekanbaru. Setelah melakukan observasi, peneliti menemukan beberapa permasalahan yang terjadi dalam proses pembelajaran, diantaranya yaitu proses pembelajaran masih didominasi oleh guru, kurangnya partisipasi peserta didik dalam pelajaran, beberapa langkah pembelajaran tidak sesuai dengan Permendikbud Nomor 22 Tahun 2016, sehingga hal tersebut perlu diperbaiki.Peneliti juga melakukan wawancara dengan 5 orang peserta didik di kelas VIII ${ }_{1}$ SMP Negeri 12 Pekanbaru yang berkemampuan heterogen untuk mengetahui kendala apa yang dialami selama proses pembelajaran matematika. Berdasarkan hasil wawancara dengan peserta didik diperoleh bahwa peserta didik tidak suka belajar matematika karena pelajarannya sulit, banyak menggunakan rumus, susah dalam perhitungan matematika, dan mereka merasa tidak percaya diri ketika ingin menjawab pertanyaan dari guru, bahkan mereka juga tidak percaya diri untuk bertanya apa yang tidak dipahami. Beberapa peserta didik mengatakan bahwa mereka senang jika belajar secara berkelompok, karena lebih terbuka untuk berdiskusi 
dan bertanya kepada temannya.Oleh karena itu, dalam proses pembelajaran perlu diterapkan suatu model pembelajaran yang dapat memaksimalkan potensi setiap peserta didik serta dapat meningkatkan rasa ingin tahu, dan membuat peserta didik lebih aktif.

Berdasarkan hasil observasi dan wawancara, peneliti menemukan beberapa kendala yang terjadi pada proses pembelajaran matematika kelas VIII ${ }_{1}$ SMP Negeri 12 Pekanbaru. Kendala yang ditemukan yaitu kurangnya keinginan peserta didik untuk mengerjakan tugas, peserta didik hanya menerima materi sehingga mereka tidak mengerti konsep dari materi yang diajarkan.Peserta didik tidak percaya diri untuk bertanya kepada guru. Untuk mengatasi permasalahan tersebut, peneliti ingin melakukan suatu tindakan untuk memperbaiki proses pembelajaran dengan menerapkan strategi pembelajaran yang sesuai yang dapat membantu peserta didik untuk berfikir, menemukan konsep, mampu berinteraksi dengan temannya, berani berpendapat dan mandiri dalam menyelesaikan permasalahan yang diberikan, sehingga peserta didik lebih mudah dalam memahami pelajaran. Jika peserta didik memahami konsep dari materi pelajaran maka hasil belajar mereka juga akan meningkat.

Salah satu solusi yang dapat dilakukan guna mengurangi pengaruh permasalahan ini adalah dengan menerapkan suatu strategi pembelajaran yang dapat membuat peserta didik menjadi aktif dalam pembelajaran sehingga peserta didik diharapkan dapat mencapai kompetensi sesuai dengan yang telah ditetapkan oleh guru dan dapat meningkatkan hasil belajar. Salah satu cara yang dapat digunakan untuk perbaikan proses pembelajaran dan untuk meningkatkan hasil belajar yaitu penerapan strategi Think-Talk-Write dalam pembelajaran kooperatif.Sebagaimana namanya, strategi ThinkTalk-Write ini memiliki makna yang sesuai dengan urutan di dalamnya, yakni think (berfikir), talk (berbicara) dan write (menulis). Strategi Think-Talk-Write ini terdiri dari tiga tahapan dimulai dengan tahap think yaitu aktivitas berfikir melalui membaca. Tahap talk yaitu mendiskusikan sesama anggota kelompok masalah yang diberikan oleh guru, kemudian belajar menyampaikan dan menjelaskan pengetahuannya dan bersosialisasi dalam bentuk diskusi kelompok. Tahap write yaitu peserta didik mampu mengkomunikasikan idenya dengan menuliskan pengetahuan yang telah didapat dari hasil diskusi dalam bentuk tulisan.

Yamin dkk (2012) menyatakan bahwa strategi Think-Talk-Write dalam pembelajaran kooperatif merupakan salah satu model pembelajaran yang dapat meningkatkan hasil belajar matematika peserta didik.Siswanto (2016) menyatakan pembelajaran Think-Talk-Write adalah sebuah pembelajaran yang dimulai dengan berfikir melalui bahan bacaan (menyimak, mengkritisi dan alternatif solusi), hasil bacaannya dikomunikasikan dengan presentasi, diskusi, dan kemudian membuat laporan hasil presentasi.Pembelajaran dengan strategi Think-Talk-Write ini dapatmelatih peserta didik untuk mengkonstruksikan pengetahuannya sendiri sehingga hasil belajar matematika peserta didik menjadi lebih baik.Selain itu, peserta didik mengerti konsep-konsep matematika yang telah diajarkan tanpa harus menghapal melainkan mamahami konsep materi pembelajaran sehingga peserta didik tidak mudah lupa dengan materi yang telah dipelajari.

Pada pelaksanaan strategi Think-Talk-Write dalam pembelajaran kooperatif ini, peneliti membentuk kelompok kooperatif yang terdiri dari 4-5 peserta didik yang dipilih secara heterogen. Pembelajaran berkelompok dilakukan dengan harapan agar peserta didik yang kurang paham dapat diajarkan dan diberitahukan oleh peserta didik yang telah paham dan peserta didik yang telah paham akan lebih menguasai karena telah menjelaskan kepada temannya. Pembelajaran kooperatif juga dapat menciptakan saling ketergantungan antar peserta didik sehingga sumber belajar bagi peserta didik tidak hanya guru dan buku ajar tetapi sesama peserta didik. 
Berdasarkan uraian yang telah dijelaskan, strategi Think-Talk-Write dalam pembelajaran kooperatif merupakan upaya untuk memperbaiki proses pembelajaran dalam meningkatkan hasil belajar matematika peserta didik yang lebih baik lagi. Strategi Think-Talk-Write dalam pembelajaran kooperatif diharapkan dapat meningkatkan hasil belajar matematika peserta didik dan pada dasarnya dibangun melalui proses berfikir, berbicara dan menulis. Oleh karena itu peneliti menerapkan strategi Think-Talk-Write dalam pembelajaran kooperatif di kelas VIII 1 SMP Negeri 12 Pekanbaru semester ganjil tahun pelajaran 2019/2020.

\section{METODE}

Penelitian dilakukan di kelas VIII 1 SMP Negeri 12 Pekanbaru, pada semester ganjil tahun 2019/2020 dengan materi relasi dan fungsi dimulai dari 18 September 2019 sampai dengan 21 Oktober 2019. Subjek penelitian adalah peserta didik kelas VIII 1 SMP Negeri 12 Pekanbaru dengan jumlah 34 peserta didik yang terdiri dari 17 orang peserta didik perempuan dan 17 orang peserta didik laki - laki dengan kemampuan yang heterogen. Jenis penelitian adalah Penelitian Tindakan Kelas (PTK) yang terdiri dari dua siklus.Menurut Arikunto (2017) PTK dilaksanakan melalui empat tahap yaitu: (1) perencanaan; (2) pelaksanaan; (3) pengamatan; dan (4) refleksi.

Instrumen pengumpul data terdiri dari: (1) Perangkat pembelajaran berupa Silabus, Rencana Pelaksanaan Pembelajaran (RPP) dan Lembar Aktivitas Peserta Didik (LKPD); (2) Instrumen pengumpul data berupa lembar pengamatan aktivitas guru dan peserta didik, serta tes hasil belajar matematika peserta didik. Data aktivitas guru dan peserta didik dikumpulkan melalui teknik observasi.Pengamat juga memberikan deskripsi tentang kesesuaian rencana pembelajaran dengan tindakan yang dilakukan untuk setiap aktivitas pembelajaran pada kolom hasil pengamatan.Data hasil belajar matematika peserta didik diperoleh melalui ulangan harian I dan ulangan harian II yang dibuat berdasarkan kisi-kisi soal UH I dan II.Tes ulangan harian digunakan untuk mengumpulkandata tentang hasil belajar matematika peserta didik setelah menyelesaikan satu siklus pembelajaran.Teknik pengumpulan data pada penelitian ini yaitu teknik observasi dan tekniktes hasil belajar matematika.Teknik analisis data yang digunakan yaitu analisis data aktivitas guru dan peserta didik, skor perkembangan individu dan penghargaan kelompok serta analisis distribusi frekuensi. Adapun analisis data pada penelitian ini adalah:

1. Analisis Data Aktivitas Guru dan Peserta Didik

Analisis data aktivitas guru dan peserta didik diperoleh berdasarkan lembar pengamatan selama proses pembelajaran. Melalui lembar pengamatan ini, peneliti melihat kelemahan dan kekurangan dari tindakan yang telah dilakukannya.Kelemahan dan kekurangan yang ditemukan harus diperbaiki untuk pertemuan selanjutnya.

2. Analisis skor perkembangan individu dan penghargaan kelompok

Skor perkembangan individu peserta didik pada siklus I diperoleh dari perolehan pada skor dasar dan skor ulangan harian I. Skor perkembangan individu peserta didik pada siklus II diperoleh dari perolehan pada skor ulangan harian I dan skor ulangan harian II. Jika jumlah peserta didik mendapat skor perkembangan 20 dan 30 lebih banyak dari peserta didik yang mendapat skor perkembangan 0 dan 10 pada siklus I dan II, maka tindakan dapat dikatakan meningkatkan hasil belajar matematika.

Analisis data skor perkembangan kelompok ditentukan dengan cara menghitung jumlah skor perkembangan individu kepada kelompok dan dihitung rata-ratanya. Rata-rata skor perkembangan setiap anggota kelompok inilah yang disebut skor kelompok. Hasil belajar peserta didik dikatakan meningkat apabila jumlah peserta 
didik yang mendapat skor perkembangan 20 dan 30 lebih banyak dari jumlah peserta didik yang mendapat skor perkembangan 0 dan 10 .

3. Analisis Distribusi Frekuensi

Distribusi frekuensi adalah bentuk penyajian data statistik berbentuk tabel, memuat angka-angka yang menggambarkan pembagian frekuensi variabel yang menjadi objek penelitian.Penyajian data menggunakan distribusi frekuensi dilakukan agar diperoleh gambaran yang jelas mengenai hasil belajar matematika peserta didik, sehingga dapat dilihat peningkatan hasil belajar matematika peserta didik.Menurut Arikunto dkk (2010), kriteria ini disusun dengan menggunakan rentang bilangan tanpa mempertimbangkan apa-apa, dilakukan dengan membagi rentang bilangan menjadi 5 yaitu Tinggi Sekali, Tinggi, Cukup, Rendah dan Rendah Sekali, sehingga diperoleh interval nilai sebagai berikut:

Tabel 1. Interval Skor Hasil Belajar Peserta Didik

\begin{tabular}{cc}
\hline Skor & Kriteria \\
\hline $0-20$ & Rendah Sekali \\
$21-40$ & Rendah \\
$41-60$ & Cukup \\
$61-80$ & Tinggi \\
$81-100$ & Tinggi Sekali \\
\hline
\end{tabular}

Jika frekuensi peserta didik yang memperoleh kriteria skor Rendah atau Rendah Sekali menurun dari sebelum dilakukan tindakan ke setelah dilakukan tindakan atau jika frekuensi peserta didik yang memperoleh kriteria skor Tinggi atau Tinggi Sekali meningkat dari sebelum dilakukan tindakan ke setelah dilakukan tindakan maka terjadi peningkatan hasil belajar.

4. Kriteria Keberhasilan Tindakan

Sumarno (2010) mengatakan apabila keadaan setelah tindakan lebih baik, maka dapat dikatakan bahwa tindakan telah berhasil, akan tetapi apabila tidak ada bedanya atau bahkan lebih buruk maka tindakan belum berhasil atau telah gagal.

Kriteria keberhasilan tindakan pada penelitian ini adalah sebagai berikut:

1) Terjadinya perbaikan proses pembelajaran

Perbaikan proses pembelajaran dilakukan berdasarkan hasil refleksi terhadap proses pembelajaran yang diperoleh melalui lembar pengamatan aktivitas guru dan peserta didik. Perbaikan proses pembelajaran terjadi jika aktivitas guru dan peserta didik semakin membaik dan kelemahan semakin sedikit.

2) Terjadinya peningkatan hasil belajar peserta didik

Peningkatan hasil belajar peserta didik dapat dilihat dari analisis distribusi frekuensi.Jika kriteria sangat rendah dan rendah mengalami penurunan frekuensi, serta terjadi peningkatan frekuensi pada kriteria tinggi dan sangat tinggi dari skor ulangan harian yang diperoleh peserta didik maka dikatakan terjadi peningkatan hasil belajar.

\section{HASIL DAN PEMBAHASAN}

Berdasarkan analisis lembar pengamatan aktivitas guru dan peserta didik selama penelitian dilakukan (6 pertemuan) dapat dikatakan bahwa pelaksanaan proses pembelajaran semakin membaik untuk setiap pertemuan. Hal ini terlihat dari hasil pengamatan yang dilakukan oleh pengamat selama proses pembelajaran. Proses pembelajaran matematika berlangsung semakin membaik pada setiap pertemuan. Kesalahan yang terjadi diperbaiki untuk pertemuan selanjutnya. Dengan membaiknya proses pembelajaran akan mempengaruhi hasil belajar matematika peserta didik. 
Data hasil belajar matematika peserta didik disajikan dalam bentuk distribusi frekuensi agar terlihat peningkatan hasil belajar peserta didik.berikut ini distribusi frekuensi dari hasil belajar matematika peserta didik kompetensi pengetahuan dari skor dasar, ulangan harian I dan ulangan harian II. Tabel 2. Distribusi Frekuensi Hasil Belajar Matematika Peserta Didik pada
Kompetensi Pengetahuan

\begin{tabular}{|c|c|c|c|c|}
\hline \multirow[b]{2}{*}{ Interval } & \multicolumn{3}{|c|}{ Frekuensi Peserta Didik } & \multirow[b]{2}{*}{ Kriteria } \\
\hline & Skor Dasar & $\begin{array}{l}\text { Ulangan Harian } \\
\text { I }\end{array}$ & $\begin{array}{l}\text { Ulangan Harian } \\
\text { II }\end{array}$ & \\
\hline $0-20$ & 2 & 0 & 0 & Sangat Rendah \\
\hline $21-40$ & 3 & 8 & 0 & Rendah \\
\hline $41-60$ & 16 & 5 & 6 & Sedang \\
\hline $61-80$ & 11 & 13 & 14 & Tinggi \\
\hline $81-100$ & 2 & 8 & 14 & Sangat Tinggi \\
\hline
\end{tabular}

Berdasarkan Tabel 2 terlihat perubahan hasil belajar antara skor dasar, ulangan harian I dan ulangan harian II.Pada skor interval kriteria sangat rendah dan rendah terjadi penurunan frekuensi peserta didik dari skor dasar ke ulangan harian I dan ulangan harian II.Pada interval kriteria sedang terjadi penurunan frekuensi peserta didik dari skor dasar ke ulangan harian I dan ulangan harian II.Pada interval kriteria tinggi terjadi peningkatan frekuensi peserta didik dari skor dasar ke ulangan harian I dan skor ulangan harian II. Pada interval kriteria sangat tinggi terjadi peningkatan frekuensi peserta didik dari skor dasar, ulangan harian I dan ulangan harian II. Hal ini menunjukkan bahwa setelah dilaksanakan tindakan terjadi peningkatan hasil belajar matematika peserta didik pada kompetensi pengetahuan ditandai dengan adanya peningkatan frekuensi peserta didik pada interval tinggi dan sangat tinggi.

Distribusi frekuensi hasil belajar matematika eserta didik pada kompetensi keterampilan pada skor dasar, ulangan harian I dan ulangan harian II disajikan pada tabel berikut:

Tabel 3. Distribusi Frekuensi Hasil Belajar Matematika Peserta Didik pada Kompetensi Keterampilan

\begin{tabular}{ccccc}
\hline & \multicolumn{3}{c}{ Frekuensi Peserta Didik } & \multirow{2}{*}{ Interval } \\
\cline { 2 - 4 } & Skor Dasar & Ulangan Harian & Ulangan Harian & \\
& & I & II & \\
\hline $0-20$ & 2 & 0 & 0 & Sangat Rendah \\
$21-40$ & 3 & 6 & 0 & Rendah \\
$41-60$ & 16 & 3 & 4 & Sedang \\
$61-80$ & 11 & 13 & 16 & Tinggi \\
$81-100$ & 2 & 12 & 14 & Sangat Tinggi \\
\hline
\end{tabular}

Berdasarkan Tabel 3 terlihat perubahan hasil belajar antara skor dasar, ulangan harian I dan ulangan harian II.Pada interval kriteria sangat rendah terjadi penurunan frekuensi peserta didik dari skor dasar ke skor ulangan harian I dan skor ulangan harian II. Pada interval kriteria rendah terjadi peningkatan dari skor dasar ke ulangan harian I dan terjadi penurunan dari skor ulangan harian I ke skor ulangan harian II.Pada interval kriteria sedang terjadi penurunan frekuensi peserta didik dari skor dasar ke ulangan harian I dan terjadi peningkatan dari skor ulangan harian I ke skor ulangan harian II.Sedangkan pada interval tinggi dan sangat tinggi terjadi peningkatan frekuensi peserta didik dari skor dasar, ulangan harian I dan ulangan harian II.Hal ini menunjukkan bahwa setelah dilaksanakan tindakan terjadi peningkatan hasil belajar matematika peserta didik 
pada kompetensi pengetahuan ditandai dengan adanya penurunan frekuensi peserta didik pada interval interval sangat rendah, rendah dan sedang, dan terjadi peningkatan frekuensi peserta didik pada interval tinggi dan sangat tinggi.

Berdasarkan kriteria keberhasilan tindakan dapat dikatakan bahwa tindakan yang peneliti lakukan telah berhasil karena adanya perbaikan proses pembelajaran dan peningkatan hasil belajar matematika peserta didik setelah diterapkan strategi

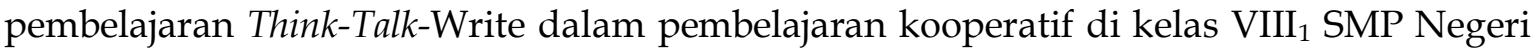
12 Pekanbaru. Namun, peneliti menemukan beberapa kendala, kekurangan yang dilakukan oleh peneliti dan peserta didik dalam proses pembelajaran. Pada siklus I masih terdapat banyak kekurangan, yaitu proses pembelajaran berlangsung belum sesuai dengan yang telah direncanakan, beberapa tahapan pembelajaran tidak terlaksana sesuai yang semestinya, peneliti kesulitan dalam mengistruksikan peserta didik dalam kelompok, peneliti belum sepenuhnya bisa mengelola waktu pembelajaran dengan baik.

Kekurangan pada siklus I ini menjadi refleksi bagi peneliti untuk memperbaiki proses pembelajaran yang akan dilaksanakan pada siklus II. Pada siklus II peneliti mampu mengelola waktu lebih baik, sehingga semua tahapan kegiatan pembelajaran terlaksana.Peserta didik terlihat lebih aktif, peserta didik sudah terbiasa dengan langkah pembelajaran yang dilaksanakan dan mampu berdiskusi dengan baik. Proses pembelajaran ini terlihat semakin baik pada setiap pertemuannya. Perbaikan proses pembelajaran ini berpengaruh terhadap hasil belajar matematika peserta didik. Selama penelitian berlangsung, diperoleh data hasil belajar matematika peserta didik kelas $\mathrm{VIII}_{1}$ SMP Negeri 12 Pekanbaru.Data yang diperoleh terlihat adanya peningkatan hasil belajar matematika peserta didik.

Berdasarkan analisis aktivitas guru dan peserta didik serta analisis hasil belajar matematika peserta didik dapat dikatakan bahwa terjadi perbaikan proses pembelajaran dan hasil belajar matematika peserta didik meningkat sehingga hasil analisis penelitian ini mendukung hipotesis yang diajukan yaitu, jika diterapkan strategi Think-Talk-Write dalam pembelajaran kooperatif, maka dapat memperbaiki proses pembelajaran dan meningkatkan hasil belajar matematika peserta didik kelas VIII ${ }_{1}$ SMP Negeri 12 Pekanbaru semester ganjil tahun pelajaran 2019/2020 pada materi pokok relasi dan fungsi.Dari penjelasan tersebut dapat dilihat bahwa strategi Think-Talk-Write dalam pembelajaran kooperatif dapat meningkatkan kemampuan berfikir secara individu dan kelompok, dan mampu berkomunikasi dalam kelompok sehingga peserta didik lebih mengerti pelajaran dan dapat meningkatkan hasil belajar.Hal ini didukung oleh penelitian Wulandari (2016) yang menyatakan bahwa Penerapan Strategi Think-TalkWrite dalam Pembelajaran Kooperatif dapat Meningkatkan Hasil Belajar Matematika Peserta Didik Kelas VII 1 SMP Negeri 1 Kubu.

\section{SIMPULAN}

Berdasarkan hasil penelitian dan pembahasan dapat disimpulkan bahwa penerapan strategi Think-Talk-Write dalam pemebelajaran kooperatif dapat memperbaiki proses pembelajaran dan meningkatkan hasil belajar matematika peserta didik kelas VIII $_{1}$ SMP Negeri 12 Pekanbaru semester ganjil tahun pelajaran 2019/2020 pada materi pokok Relasi dan Fungsi.

\section{UCAPAN TERIMA KASIH}

Ucapan terima kasih disampaikan kepada lembaga yang telah mendukung terlaksanya penelitian ini.Ucapan terima kasih ditujukan kepada Universitas Riau, Dinas Pendidikan dan Kebudayaan Provinsi Riau dan SMP Negeri 12 Pekanbaru. 
DAFTAR PUSTAKA

Arikunto, Suharsimi., \& Ceppi.Safruddin.(2010). Evaluasi Program Pendidikan. Bumi Aksara. Jakarta.

Arikunto, Suharsimi., Suhardjono., \& Supardi. (2017). Penelitian Tindakan Kelas. Bumi Aksara. Jakarta.

Made, I. Surat. (2016). Pembentukan Karakter dan Kemampuan Berpikir Logis Siswa Melalui Pembelajaran Matematika Berbasis Saintifik.Jurnal EMASAINS Volume V, Nomor 1, Maret Tahun 2016.

https://ojs.ikippgribali.ac.id/index.php/emasains/article/download/20/17/

Permendikbud Nomor 58 Tahun 2014 tentang Kurikulum 2013 Sekolah Menengah Pertama/Madrasah Tsanawiyah

Permendikbud Nomor 22 Tahun 2016 tentang Standar Isi

Permendikbud Nomor 23 Tahun 2016 tentang Standar Penilaian Pendidikan Dasar dan Menengah

Sumarno, (2010). Pedoman Pelaksanaan Penelitian Tindakan Kelas. Dikti Depdikbud. Yogyakarta

Siswanto, Wahyudi., \& Ariani. Dewi. (2016). Model Pembelajaran Menulis Cerita. Refika Aditama. Bandung.

Yamin, Martinis., \& Bansu. Ansari. (2012). Taktik Mengembangkan Kemampuan Individual Siswa. GP Press Group. Jakarta.

Wulandari, Sari. (2016).Penerapan Strategi Think-Talk-Write dalam Pembelajaran Kooperatif

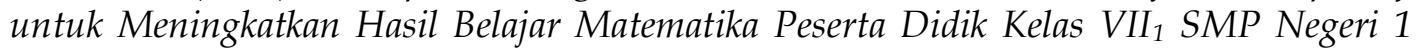
Kubuhttps://media.neliti.com/media/publications/189753-ID-penerapanstrategi-think-talk-write-dala.pdf 